May 2003 • NREL/CP-520-33554

\title{
Criteria for the Design of GalnP/GaAs/Ge Triple-Junction Cells to Optimize Their Performance Outdoors
}

W.E. McMahon, S. Kurtz, K. Emery, and M.S. Young

Presented at the National Center for Photovoltaics and Solar Program Review Meeting Denver, Colorado March 24-26, 2003

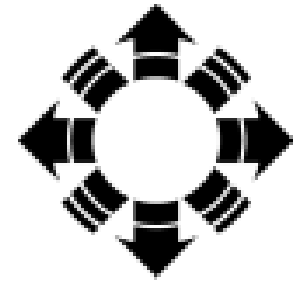

\section{NPEI}

National Renewable Energy Laboratory

1617 Cole Boulevard

Golden, Colorado 80401-3393

NREL is a U.S. Department of Energy Laboratory

Operated by Midwest Research Institute $\bullet$ Battelle $\bullet$ Bechtel

Contract No. DE-AC36-99-G010337 


\section{NOTICE}

The submitted manuscript has been offered by an employee of the Midwest Research Institute (MRI), a contractor of the US Government under Contract No. DE-AC36-99G010337. Accordingly, the US Government and MRI retain a nonexclusive royalty-free license to publish or reproduce the published form of this contribution, or allow others to do so, for US Government purposes.

This report was prepared as an account of work sponsored by an agency of the United States government. Neither the United States government nor any agency thereof, nor any of their employees, makes any warranty, express or implied, or assumes any legal liability or responsibility for the accuracy, completeness, or usefulness of any information, apparatus, product, or process disclosed, or represents that its use would not infringe privately owned rights. Reference herein to any specific commercial product, process, or service by trade name, trademark, manufacturer, or otherwise does not necessarily constitute or imply its endorsement, recommendation, or favoring by the United States government or any agency thereof. The views and opinions of authors expressed herein do not necessarily state or reflect those of the United States government or any agency thereof.

Available electronically at http://www.osti.gov/bridge

Available for a processing fee to U.S. Department of Energy and its contractors, in paper, from:

U.S. Department of Energy

Office of Scientific and Technical Information

P.O. Box 62

Oak Ridge, TN 37831-0062

phone: 865.576.8401

fax: 865.576.5728

email: reports@adonis.osti.gov

Available for sale to the public, in paper, from:

U.S. Department of Commerce

National Technical Information Service

5285 Port Royal Road

Springfield, VA 22161

phone: 800.553 .6847

fax: 703.605.6900

email: orders@ntis.fedworld.gov

online ordering: http://www.ntis.gov/ordering.htm

Printed on paper containing at least $50 \%$ wastepaper, including $20 \%$ postconsumer waste 


\title{
Criteria for the Design of GaInP/GaAs/Ge Triple-Junction Cells to Optimize Their Performance Outdoors
}

\author{
W.E. McMahon, Sarah Kurtz, K. Emery, and M.S. Young \\ National Renewable Energy Laboratory \\ 1617 Cole Blvd., Golden, CO 80401
}

\begin{abstract}
This paper investigates which reference spectrum should be used to design GaInP/GaAs/Ge triple-junction cells (at $300 \mathrm{~K}$ ) in order to optimize their performance outdoors (at elevated temperatures). The outdoor performance is simulated using direct spectra from the recently proposed Module Energy Rating Procedure. We find that triplejunction cells designed for AM1.5D, low-AOD and AM1.5G standard spectra at $300 \mathrm{~K}$ all work well for maximizing daily energy production at elevated temperatures. AM1.5G cells are the best choice for midday power production, whereas AM1.5D cells are the best choice for power production during the morning and evening. Performance of cells optimized for a newly proposed Low-AOD spectrum is intermediate between these two extremes.
\end{abstract}

\section{Introduction}

To facilitate solar cell design, standard spectra have been defined which approximate the real solar spectrum under a handful of conditions. In concentrator systems, cells will be illuminated only by the direct solar spectrum, so an "air mass 1.5 direct" (AM1.5D) standard spectrum [1] has been defined for illuminating concentrator cells in a laboratory. Although this standard seems to work well for singlejunction concentrator cells, a triple-junction cell designed for the AM1.5D standard spectrum illumination at $300 \mathrm{~K}$ (hereafter "an AM1.5D cell") may not perform well during actual use in a concentrating collector. In fact, an outdoor test at a site well-suited for concentrator applications has shown that an AM0 ("air mass zero") triple-junction cell can actually performed better than an AM1.5D cell under some conditions [2]. This suggests that an alternative design spectrum (or spectra) for multijunction concentrator cells is needed.

In this paper, we simulate both the design and performance of cells under a variety of direct spectra. To model the power production of triple-junction cells, spectra were taken from a newly proposed Module Energy Rating Procedure [3]. This allowed us to simulate the performance of cells over the course of several representative "standard days." Surprisingly, we find that an AM1.5G ("air mass 1.5 global" [1]) triple-junction cell outperforms an AM1.5D triple-junction cell during the most intense, midday hours. However, the AM1.5D cell outperforms the AM1.5G cell during the morning and evening.

Because the AM1.5D spectrum does not, in general, work well for midday concentrator applications, an alternative design spectrum is needed. For this reason, this paper includes the "Low-AOD" (low aerosol-optical-depth) direct spectrum described in reference [4]. A very similar "clear-sky" direct spectrum is described in reference [5]. Our conclusions regarding the "Low-AOD" direct spectrum apply equally to the "clear-sky" direct spectrum.

Not surprisingly, a cell designed for the Low-AOD spectrum performs quite well. Averaged over an entire day, the total energy production of the AM1.5D, AM1.5G and Low-AOD cells is about the same. The choice of design spectrum will therefore depend on the exact needs of the end user.

Our discussion will be limited to idealized $\left(\mathrm{N}_{\text {photoelectrons }}=\right.$ $\mathrm{N}_{\text {absorbed photons }}$ ) two-terminal triple-junction cells with a $\mathrm{Ge}$ bottom cell, GaAs middle cell and a GaInP top cell with direct band gaps $\left(\mathrm{E}_{\mathrm{g}} \mathrm{s}\right)$ of $0.8,1.424$ and $1.85 \mathrm{eV}$, respectively. However, the conclusions will be equally valid for a $\mathrm{GaInP} / \mathrm{GaAs}$ two-terminal tandem cell, since the Ge bottom cell does not affect the design of the GaInP or GaAs junctions for any reasonable cell design.

This study considers the choice of spectrum for designing cells at $300 \mathrm{~K}$ under one-sun illumination for use at elevated temperatures under 500x illumination. Within the context of this study, our calculations show that the effect of concentration is negligible. Temperature effects are quite important, however, and will be discussed later in this paper.

\section{Background}

To begin, it is important to understand how the top cell thickness affects the performance of $\mathrm{GaInP} / \mathrm{GaAs} / \mathrm{Ge}$ triplejunction cells. At one extreme, a very thin GaInP top cell will produce almost no photocurrent, so the entire triplejunction cell will be photocurrent-limited by the top cell. At the other extreme, a triple-junction cell with a very thick top cell will generally be photocurrent-limited by the middle (GaAs) cell. Because a triple-junction cell must be currentmatched for optimal performance, the optimal top cell thickness lies between these two extremes, and will depend on the incident spectrum. This last point is very important, and is the focus of this paper.

As an example, in Fig. 1 we use the methods of reference [6] to simulate the power produced by a triple-junction cell as a function of top cell thickness $\left(t_{\text {top }}\right.$ ) under illumination by four standard spectra at $300 \mathrm{~K}$. The peak of each curve has been labeled, and the corresponding $t_{\text {top }}$ has been indicated on the horizontal axis. For ease of comparison, these same four values of $t_{\text {top }}$ are also labeled on subsequent plots. Of the four spectra, the AM0 spectrum is most heavily weighted toward photons with an energy greater than the GaInP top cell's band gap. Therefore, the optimal $t_{\text {top }}$ for AM0 is the thinnest. Because the other spectra contain fractionally less of this short-wavelength light, the top cells must be thicker for optimal performance. 


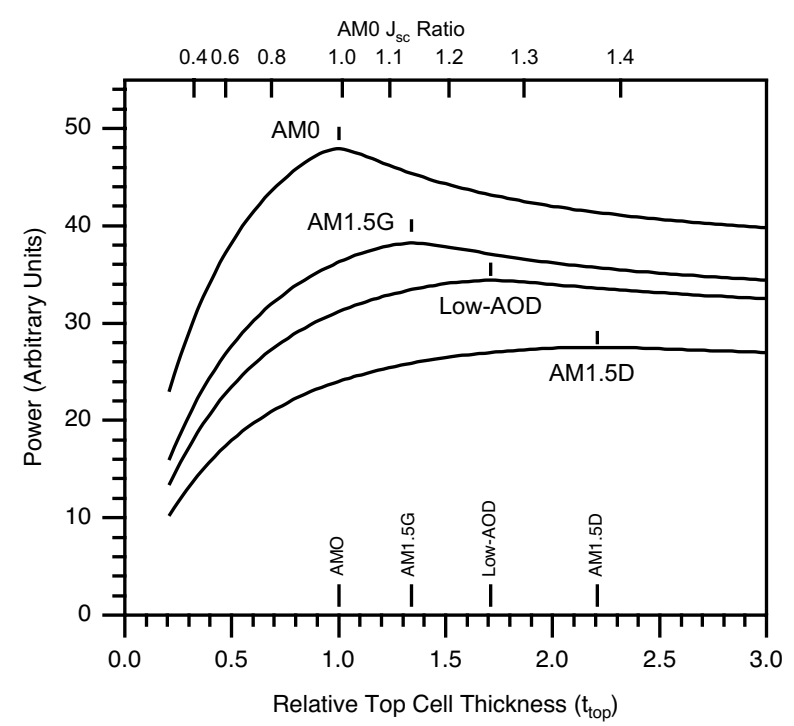

Figure 1. Calculated power produced by a $\mathrm{GaInP} / \mathrm{GaAs} / \mathrm{Ge}$ triple-junction cell as a function of relative top cell thickness for four standard spectra, under one-sun illumination at $300 \mathrm{~K}$.

The $t_{\text {top }}$ corresponding to the maximum of each curve is indicated just above the bottom axis in this and subsequent figures. The decoupled $\mathrm{J}_{\mathrm{sc}}$ ratio $\left(\mathrm{J}_{\mathrm{sc}, \mathrm{GaInP}} / \mathrm{J}_{\mathrm{sc}, \mathrm{GaAs}}\right)$ under AM0 illumination is shown along the top axis (also shown in subsequent figures).

Notice that $t_{\text {top }}$ is expressed as a relative thickness, stated as a fraction of the optimal top cell thickness for AM0 illumination. Because the actual top cell thickness depends on specific cell design choices, it is not a good basis of comparison between cells outside the confines of a selfcontained, self-consistent study. For comparison with triple-junction cells outside this study, the top axis shows the $\mathrm{J}_{\mathrm{sc}}$ ratio $\left(\mathrm{J}_{\mathrm{sc}, \mathrm{GaInP}} / \mathrm{J}_{\mathrm{sc}, \mathrm{GaAs}}\right)$ of decoupled short-circuit photocurrents, measured under AM0 illumination. By "decoupled," we mean that the photocurrent produced by each cell (GaInP or GaAs) is calculated independently without being current-limited by the other cell. A method for measuring this ratio experimentally can be found in reference [7].

\section{Results}

In Fig. 2 we use solar spectra from the Module Energy Rating Procedure [3] to simulate the power produced by a triple-junction cell under 500x illumination as a function of $t_{\text {top }}$ and time of day for a standard "hot sunny day." Elevated cell temperature during operation is simulated by the formula [8] given in the figure caption, using the hourly ambient temperatures given for the standard days in reference [3]. Notice that for each hour of the day the maximum shifts to a different value of $t_{\text {top }}$. This is directly related to changes in the spectral distribution of the incident spectrum (and to changes in cell temperature). If a given spectrum contains relatively more high-energy photons (hn $\left.>\mathrm{E}_{\mathrm{g}, \mathrm{GaInP}}\right)$, $\mathrm{t}_{\text {top }}$ will be thinner. For most hours of the day the maximum of each curve (and therefore the optimal $t_{\text {top }}$ ) falls between 1.3 and 1.6. Notice that an AM1.5G cell lies within this range and will therefore perform well throughout most of the day. An AM1.5D cell will be optimal only for the 8:00 AM (hour 8) and 6:00 PM (hour 18) spectra, and an AM0 cell is never optimal.

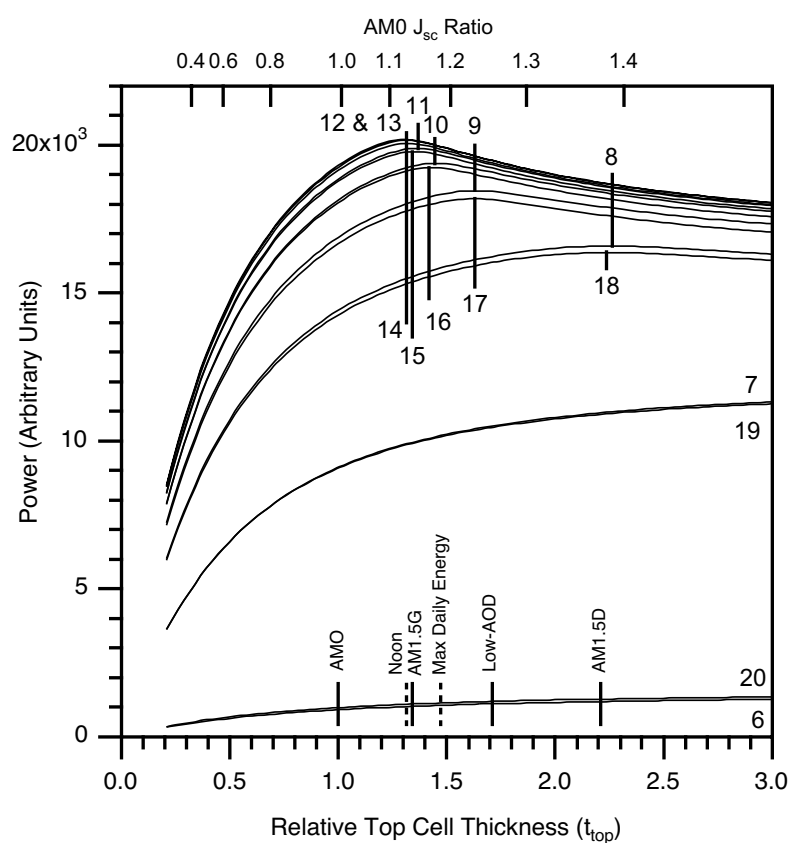

Figure 2. Calculated power for a triple-junction cell under $500 \mathrm{x}$ illumination as a function of $\mathrm{t}_{\text {top }}$ for each daylight hour of a standard "hot sunny day." The line used to label each curve is positioned at the curve maximum. The cell temperature for each hour is:

$\mathrm{T}_{\text {cell, hour }}=\mathrm{T}_{\text {ambient, hour }}+\left(40^{\circ} \mathrm{C}\right) \cdot($ Irradiance hour $/ 800 \mathrm{Watts})$.

The $t_{\text {top }}$ giving the maximum power at noon (hour 12) and the maximum daily energy have been labeled just above the bottom axis.

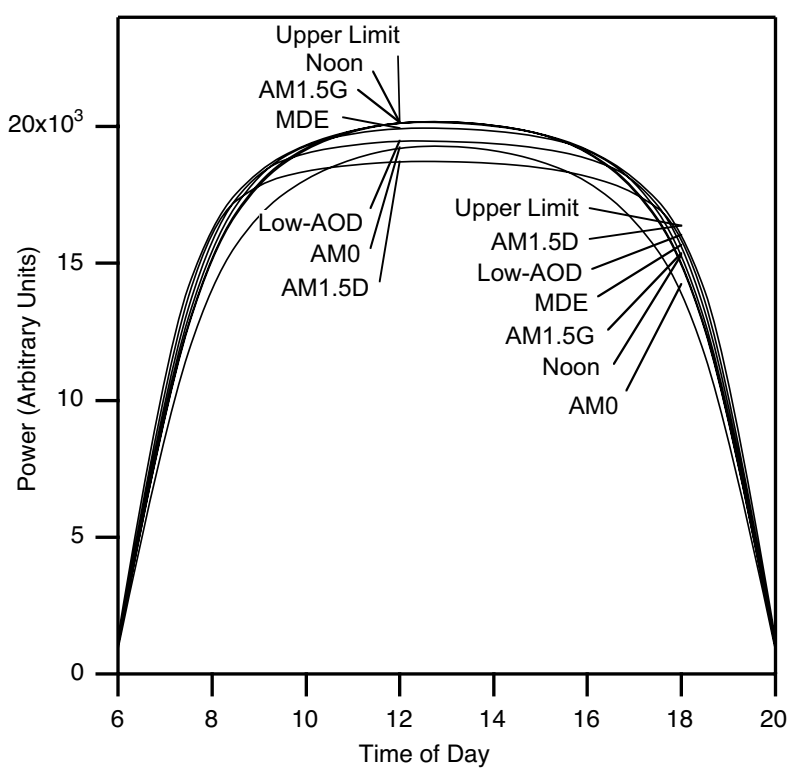

Figure 3. Calculated power (at 500x concentration) on a standard "hot sunny day" as a function of time of day for triple-junction cells designed for different purposes. The upper limit is for a fictitious cell in which $t_{\text {top }}$ is reoptimized for each hour of the day. The other six cells have the $t_{\text {top }} \mathrm{s}$ shown along the bottom axis of Fig. 2 $(\mathrm{MDE}=$ Maximum Daily Energy). The (elevated) cell temperature for each hour of the day is the same as in Fig. 2.

The curves are labeled in order of performance at noon and 6:00 PM. 
Table 1. Performance of cells designed for condition B and used for condition A (at 500x concentration). For each of the eight cells, the corresponding decoupled $\mathrm{J}_{\mathrm{sc}}$ ratio and $\mathrm{t}_{\text {top }}$ are given (leftmost two columns). The HS Day, Nice Day and CS Day cells were optimized for maximum daily energy. The other four cells were optimized for maximum power under the given spectra.

The cell temperature is $300 \mathrm{~K}$ for the AM0, AM1.5G and AM1.5D cells. The cell temperature for the other cells is given by:

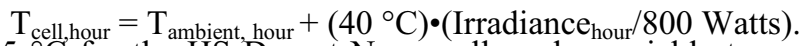

This gives a temperature of $85^{\circ} \mathrm{C}$ for the HS Day at Noon cell, and a variable temperature for the remaining three cells.

\begin{tabular}{|c|c|c|c|c|c|c|}
\hline $\begin{array}{c}\text { AM0 } \\
J_{s c} \\
\text { Ratio }\end{array}$ & $t_{t o p}$ & $\begin{array}{c}\text { A } \\
\text { B }\end{array}$ & $\begin{array}{c}\text { HS Day at Noon } \\
\text { (Power) }\end{array}$ & $\begin{array}{c}\text { Hot Sunny Day } \\
\text { (Daily Energy) }\end{array}$ & $\begin{array}{c}\text { Nice Day } \\
\text { (Daily } \\
\text { Energy) }\end{array}$ & $\begin{array}{c}\text { Cold Sunny Day } \\
\text { (Daily Energy) }\end{array}$ \\
\hline 1.00 & 1.00 & AM0 & 95.5 & 93.7 & 93.2 & 93.2 \\
\hline 1.15 & 1.32 & HS Day at Noon & 100.0 & 99.4 & 99.1 & 99.1 \\
\hline 1.16 & 1.34 & AM1.5G & 99.9 & 99.6 & 99.4 & 99.3 \\
\hline 1.20 & 1.47 & Hot Sunny Day & 98.9 & 100.0 & 100.0 & 100.0 \\
\hline 1.22 & 1.53 & Nice Day & 98.4 & 100.0 & 100.0 & 100.0 \\
\hline 1.23 & 1.55 & Cold Sunny Day & 98.1 & 99.9 & 100.0 & 100.0 \\
\hline 1.27 & 1.71 & Low-AOD & 96.6 & 99.5 & 99.7 & 99.7 \\
\hline 1.37 & 2.21 & AM1.5D & 92.9 & 97.6 & 97.9 & 98.2 \\
\hline
\end{tabular}

If the power curves shown in Fig. 2 are summed to give the total energy produced by a given cell over the course of an entire day, the maximum daily energy (MDE) will be produced by a cell with a $t_{\text {top }}$ of 1.47 . Not surprisingly, this value gives nearly optimal power production during the peak power-producing hours of the day.

These trends can also be seen in Fig. 3. Here we use the curves of Fig. 2 to plot the power output of seven different triple-junction cells as a function of time of day during a standard hot sunny day. The uppermost curve is for a fictitious triple-junction cell for which $t_{\text {top }}$ can be varied throughout the day to give optimal power production. The remaining six curves are for triple-junction cells with a fixed $t_{\text {top }}$ designed for specific conditions. The AM0, AM1.5G, Low-AOD, and AM1.5D cells are designed for maximum power production under their respective spectra at $300 \mathrm{~K}$. The "noon" cell is optimized for power production at noon (at an elevated temperature). Finally, the "MDE" cell produces the maximum daily energy (at a varying elevated temperature). The curves are labeled in decreasing order of power produced at noon and at 6:00 PM. Although unlabelled, the arrangement of curves is the same for the morning as it is for the evening.

The noon, AM1.5G and MDE cells all produce nearoptimal power during the middle peak-power production portion of the day. In Fig. 3 they are very close to the upper limit given by the fictitious variable-top-cell curve during the middle portion of the day. Because the $t_{\text {top }} s$ for these three cells are between 1.3 and 1.6, they lie near the maxima of the majority of the highest curves in Fig. 2. However, performance during the morning and evening hours is compromised. At the other thickness extreme, the AM1.5D cell performs best during the morning and evening, and poorly during the middle of the day. This can be verified in Fig. 2, where the "AM1.5D" $\mathrm{t}_{\text {top }}$ lies near curve maxima at 8:00 AM and 6:00 PM. The Low-AOD cell lies between these two extremes, and the AM0 cell never performs well because its $t_{\text {top }}$ is always too small.

All of the curves shown in Figs. 2 and 3 are for triplejunction cell performance simulated during a standard hot sunny day. But for most applications, simply discussing performance during a single day is not adequate. In addition, one must ask how a cell optimized for this one hot sunny day would perform on different days throughout the year, during which the incident spectra will be different.

A comparison of this sort is shown in Table 1 . The numbers in the table are the percentage of optimal performance, defined as:

(Performance if designed for $B$ and used for $A$ )

$\frac{(\text { Performance if designed for } A \text { and used for } A)}{A} \times 100 \%$,

where "performance" is defined in terms of energy for the three standard days, and power for the "hot sunny day at noon" spectrum.

For daily energy production, all cells except for the AM0 cell perform quite well. The performance losses are all $\leq 3 \%$. However, if midday power production is also considered, cells with thinner $t_{\text {top }} s$ perform noticeably better. If both midday power and total daily energy are important, the hot sunny day cell performs the best, closely followed by the AM1.5G cell.

Finally, the effect of temperature should be considered. As cell temperature is increased, all three band gaps decrease, so the top (GaInP) cell can absorb a proportionally larger portion of the incident spectrum. Therefore, as the cell temperature is increased, $t_{\text {top }}$ should be decreased for optimal performance.

This temperature effect can be clearly seen in Fig. 4, where cell performance is plotted for three different values of the temperature coefficient $\mathrm{m}$ (see figure caption). For $\mathrm{m}=0^{\circ} \mathrm{C}$, the cell operating temperature will be near room temperature, so designing for a Low-AOD spectrum at $300 \mathrm{~K}$ works quite well. This is easy to understand, since both the design spectrum and the design temperature were close to the operating conditions.

At very high operating temperatures $\left(\mathrm{m}=80^{\circ} \mathrm{C}\right)$, a cell designed for an AM1.5G spectrum at $300 \mathrm{~K}$ will work the best. In this case, both the design temperature and spectrum are different from the actual operating condition). However, raising the cell temperature and making the 


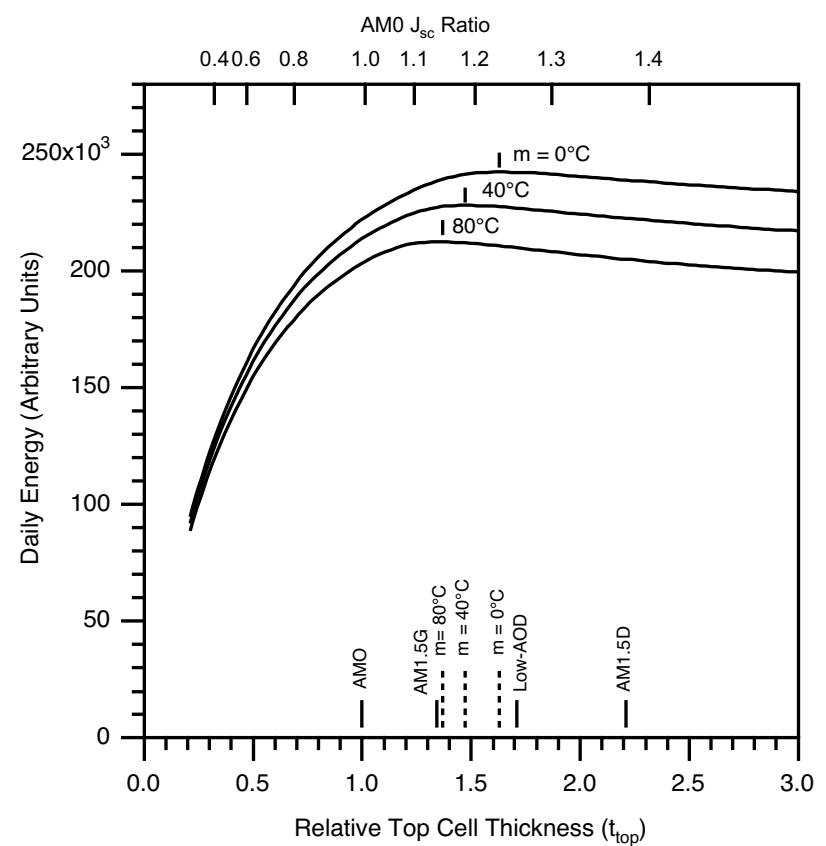

Figure 4. Cell performance at 500x concentration for the standard "hot sunny day" as a function of operating temperature, where the cell temperature is given by:

$\mathrm{T}_{\text {cell,hour }}=\mathrm{T}_{\text {ambient, hour }}+\mathrm{m} \bullet$ (Irradiance hour $\left./ 800 \mathrm{Watts}\right)$. As the cell temperature is increased, $t_{\text {top }}$ must be reduced for optimal performance.

spectrum more blue-rich affect the cell design in the same way (the optimal $t_{\text {top }}$ is thinner), so the two errors cancel each other out. Of course, the most accurate and least confusing way to simulate cell performance (and design cells) would be to use the most accurate spectrum (LowAOD) and a representative elevated cell temperature (not $300 \mathrm{~K})$.

A final subtlety is that the performance curves in Fig. 4 are asymmetric. When it comes to uncertainties in the operating temperature, it is better to make the top cell a little too thick instead of a little too thin. (The same performance curve asymmetry can be seen in Figs. 1 and 2.)

\section{Conclusions}

Because spectral variations can have a dramatic effect on the performance of triple-junction solar cells, the choice of design spectrum requires some careful consideration. In this study we find that triple-junction cells designed for AM1.5D, Low-AOD and AM1.5G standard spectra at $300 \mathrm{~K}$ all work well for maximizing daily energy production at elevated temperatures. AM1.5G cells are the best choice for midday power production, whereas AM1.5D cells are the best choice during the morning and evening. Low-AOD cell performance is intermediate between these two extremes.

\section{Acknowledgments}

The authors would like to thank Bill Marion for providing the "standard day" spectra used in this study. This work was performed at the National Renewable Energy Laboratory under DOE contract \# DE-AC3699GO10337.

\section{REFERENCES}

[1] ASTM Standard Tables for Reference Solar Spectral Irradiance at Air Mass 1.5: Direct Normal and Hemispherical for a $37^{\circ}$ Tilted Surface, Standard G159-99, American Society for Testing and Materials, West Conshohocken, PA (1999).

[2] M.J. O'Neill and A.J. McDanal, "Development of Terrestrial Concentrator Modules Using High-Efficiency Multi-Junction Solar Cells," Proceedings of the 2001 NCPV Program Review Meeting, p. 281 (2001).

[3] IEEE P1479 Draft 5 "Recommended Practice for the Evaluation of Photovoltaic Module Energy Production" (IEEE draft standard).

[4] K. Emery, D. Myers and S. Kurtz, "What is the Appropriate Spectrum for Characterizing Concentrator Cells?," 29th IEEE PVSC (2002).

[5] D.R. Myers, K. Emery and C. Gueymard, "Proposed Reference Spectral Irradiance Standards to Improve Concentrating Photovoltaic System Design and Performance Evaluation," 29th IEEE PVSC (2002).

[6] Sarah R. Kurtz, P. Faine and J.M. Olson, "Modeling of Two-Junction, Series-Connected Tandem Solar Cells Using Top-Cell Thickness as an Adjustable Parameter," J. Appl. Phys. 68, p. 1890 (1990).

[7] S.R. Kurtz, K. Emery and J.M. Olson, "Methods for Analysis of Two-Junction, Two-Terminal Photovoltaic Devices," Proceedings of the First World Conference on Photovoltaic Energy Conversion, p. 1733 (1994).

[8] Standard ASTM E1036M-A1, "Method of Determining the Nominal Operating Cell Temperature (NOCT) of an Array or Module," American Society for Testing and Materials, West Conshohocken, PA, USA. 


\section{REPORT DOCUMENTATION PAGE}

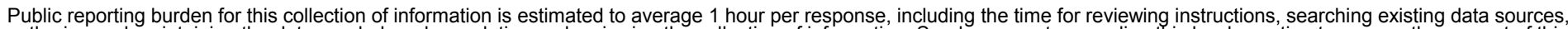

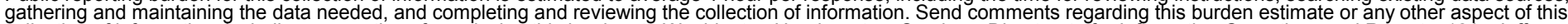

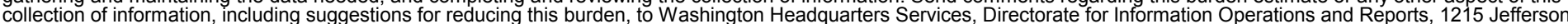

Davis Highway, Suite 1204, Arlington, VA 22202-4302, and to the Office of Management and Budget, Paperwork Reduction Project (0704-0188), Washington, DC 20503.
1. AGENCY USE ONLY (Leave blank)
2. REPORT DATE
May 2003
3. REPORT TYPE AND DATES COVERED
Conference Paper

4. TITLE AND SUBTITLE

Criteria for the Design of GalnP/GaAs/Ge Triple-Junction Cells to Optimize Their

Performance Outdoors

5. FUNDING NUMBERS

PVP3.4902

\section{AUTHOR(S)}

'W.E. McMahon, S. Kurtz, K. Emery, and M.S. Young

7. PERFORMING ORGANIZATION NAME(S) AND ADDRESS(ES) National Renewable Energy Laboratory

1617 Cole Blvd.

Golden, CO 80401-3393

9. SPONSORING/MONITORING AGENCY NAME(S) AND ADDRESS(ES)
8. PERFORMING ORGANIZATION REPORT NUMBER

NREL/CP-520-33554

10. SPONSORING/MONITORING AGENCY REPORT NUMBER

11. SUPPLEMENTARY NOTES

12a. DISTRIBUTION/AVAILABILITY STATEMENT National Technical Information Service

U.S. Department of Commerce

5285 Port Royal Road

Springfield, VA 22161

13. ABSTRACT (Maximum 200 words)

This paper investigates which reference spectrum should be used to design GalnP/GaAs/Ge triple-junction cells (at $300 \mathrm{~K}$ ) in order to optimize their performance outdoors (at elevated temperatures). The outdoor performance is simulated using direct spectra from the recently proposed Module Energy Rating Procedure. We find that triple-junction cells designed for AM1.5D, low-AOD and AM1.5G standard spectra at $300 \mathrm{~K}$ all work well for maximizing daily energy production at elevated temperatures. AM1.5G cells are the best choice for midday power production, whereas AM1.5D cells are the best choice for power production during the morning and evening. Performance of cells optimized for a newly proposed Low-AOD spectrum is intermediate between these two extremes.

14. SUBJECT TERMS

CIGS; Module Energy Rating Procedure; PV concentrator cells; reference spectrum; triple-junction solar cells

15. NUMBER OF PAGES

16. PRICE CODE

17. SECURITY CLASSIFICATION OF REPORT

Unclassified
18. SECURITY CLASSIFICATION OF THIS PAGE Unclassified
19. SECURITY CLASSIFICATION OF ABSTRACT Unclassified
20. LIMITATION OF ABSTRACT

UL 